\title{
Trauma and Post-Trauma in the Book of Ezekiel
}

\author{
REFAEL FURMAN (BEN GURION UNIVERSITY, ISRAEL)
}

\begin{abstract}
Reading the Book of Ezekiel in the light of modern sociological and psychological research dealing with emigration, exile and refugees, leads to a better and brighter understanding of the human experience in the Babylonian exile. In Ezekiel's oracles, prophecies and speeches (especially texts such as Ezekiel 3:22-27, 4:4-8 and chapters 16; 23) there are signs of post-traumatic symptoms, not necessarily individual, rather communal. The present article examines the texts in question in the light of clinical, sociological and philosophical literature dealing with forced-migration related trauma.
\end{abstract}

KEYWORDS: Trauma, PTSD, Ezekiel, Exile.

\section{A INTRODUCTION}

The Babylonian exile constitutes a turning-point in the history of the Jewish people in the biblical period. Many of the biblical books deal with exile from different vantage points - as a future punishment in the words of the prophets, as the reality in which a prophet lives, or as "exilic" literature originating in the historical reality that generated the exile. In light of the above distinction, the book of Ezekiel may be considered an "exilic" work. The book reveals nothing about the history of the Judean exiles in Babylon, their way of life, their occupations, and what happened to them in Babylon. However, its spirit, its interpretation of reality, and the theological perception of fate it reflects constitute the inception of exilic thought in biblical literature.

The trauma of exile is the central axis around which the book of Ezekiel is formed. The words and descriptions of its author express the feelings of dread, shame, detachment, and abandonment that overpowered the community of exiles. The present study aims to uncover and clarify the traumatic and posttraumatic foundations in the book of Ezekiel. Poser's work demonstrated that psycho-traumatology can assist in understanding the use of angry and violent language featured in the book of Ezekiel (see further in this essay). ${ }^{1}$ The aim of the present study will be pursued according to the following stages: 1: locating and discussing the literary traumatic expressions in different texts in the book; 2 :

* Submitted: 28/11/2019; peer-reviewed: 09/03/2020; accepted: 10/03/2020. Refael Furman, "Trauma and Post-Trauma in the Book of Ezekiel," Old Testament Essays 33 no. 1 (2020): 32 - 59. DOI: https://doi.org/10.17159/2312-3621/2020/v33n1a4.

1 Ruth Poser, "No Words: The Book of Ezekiel as Trauma Literature and a Response to Exile," in Bible Through the Lens of Trauma (ed. Elizabeth Boase and Christopher G. Frechette; Atlanta: SBL Press, 2010), 27-48. 
examining these texts in light of socio-psychological scholarly literature (presented in the first part of the essay); 3: formulating conclusions about the book's authors and their communities in light of the relevant texts in the book of Ezekiel, and in light of socio-psychological research on trauma and its impact on human beings and communities. ${ }^{2}$

\section{B TRAUMA AND POST-TRAUMA IN EXILIC EXPERIENCE}

In his book, Beyond Guilt and Atonement, Amery attempts an in-depth analysis of the experiences, feelings, and pain he experienced during and after the Holocaust in Europe. ${ }^{3}$ In his essays, "How much home does a person need?" and "Resentment," Amery tackles the problem of the strangeness and estrangement inherent in an exilic life imposed on a human being. Being torn away from one's homeland is an irrevocable event, he claims, because even if a person eventually returns to his homeland, the time he has lost can never be restored. ${ }^{4} \mathrm{~A}$ homeland means security. Every human being needs to know that he has a homeland (even if he does not reside there), a place to which he can always return - a "home" in this world. A homeland is much more than its perceptible manifestations (soil, cities, buildings, people). It is first and foremost a consciousness that a person develops from his early childhood, which enables him to decipher the unique dialectic of his surroundings. ${ }^{5} \mathrm{He}$ learns to decipher signs and nuances, to define people socially on the sole basis of their way of speaking, their facial features, and dress. These are things that an adult foreigner is incapable of doing spontaneously and will succeed only through considerable spiritual and intellectual effort. Amery compares this kind of knowledge to the knowledge of one's mother language at young age, when one is still unaware of its grammatical rules. This is the kind of knowledge that grows inside a person, and familiarity with the dialectics of life in the homeland grants him a sense of security.

Thus, according to Amery, a person can have only one homeland, and it constitutes a one-time-event in the life of human beings, whose characters are formed during childhood and adolescence. A person who has lost his homeland is "a lost person," even if he has been accustomed to life in a foreign place for

2 For a general review of the subject see: Paul M. Joyce, "The Prophets and Psychological Interpretation," in Prophecy and the Prophets in Ancient Israel: Proceedings of the Oxford Old Testament Seminar (ed. John Day; New York: T \& T Clark 2010) 133-148.

3 Jean Amery, Beyond Guilt and Atonement (Hebrew; Tel Aviv: Am Oved, 2000). By discussing Amery's writings, there is no intention to compare the exile in Babylon and the Holocaust as historical events. My aim is to examine the term "trauma" from different angles linked to various events.

4 Amery, Beyond Guilt, 97.

5 Amery, Beyond Guilt, 106-110. 
many years. He will never experience the absolute existential security that he felt in the sovereign national state that had been his homeland from early childhood.

Amery's words make room for the assumption that if a person is bound to his homeland with such strong ties, he or she will only leave it under extreme duress (nowadays people leave their homeland for good prospects, not extreme necessity, however this fact does not diminish the difficulties of immigration). Such necessity can either follow from external causes, like in the case of the Babylonian exile, where the exiles were deported by force under violent circumstances; or from inner causes, that is, the mental state of the emigrant who for some reason is unable to continue living in his homeland (mostly external causes, such as the financial or social situation of the person or his personal security, are at stake). Emigration is often the result of dangers threatening the life of a person in his homeland. Perez has claimed that even people who emigrate of their own volition (people whose lives are not in danger in their homeland) should be seen as exiles because they no longer live in their homeland. ${ }^{6}$ Thus, sometimes the homeland becomes a romantic ideal in the eyes of the emigrant and his descendants.

The experience of living in a foreign land, in exile, is traumatic, especially in the period immediately following the migration. A traumatic experience is an unusual experience, which a person perceives as a potential threat against the life or well-being of himself or of those surrounding him.Hence, it is often a violent ${ }^{7}$ event accompanied by a feeling of horror and helplessness, such as war (in the battlefield as well as when harming civilians), captivity, kidnapping, torture, a violent criminal act, sexual assault, or natural disaster. Additional kinds of events may be added to this list, such as traffic accidents, work accidents, extreme poverty, threats of violence, extortion, and human trafficking. These kinds of events undermine the world-view and beliefs of a person, and in this way his feelings of security and self-esteem are harmed.The study of trauma intensified ${ }^{8}$ during the 1970s, mainly due to the Vietnam War and the increasing awareness to sexual abuse. ${ }^{9}$ This line of research echoed early $20^{\text {th }}$ century research done

$6 \quad$ Paule Pérez, "Exiles Masked, Masks of Exile," Diogenes 54 (2007): 73-80.

7 Juan M. Peña et al., "Traumatic Events and Symptoms among Mexican Deportees in a Border Community," Journal of Immigrant and Refugee Studies 15 (2017): 36-52. 8 Aiton Birnbaum, "Collective Trauma and Post-Traumatic Symptoms in the Biblical Narrative of Ancient Israel," Mental Health, Religion and Culture 11 (2008): 533-546.

9 A prominent and comprehensive study of trauma, ramifications of trauma and the possibilities of healing was done in 1995 by Tedeschi and Calhoun. Their milestone study examines the religious and philosophical background of the human suffering and traumatic experience, physical and psychological effects of trauma, the coping and prospect of psychological growth for victims of traumatic experiences, and practical guidelines for healing. See Richard G. Tedeschi and Lawrence G. Calhoun, Trauma and Transformation: Growing in the Aftermath of Suffering (Thousand Oaks: SAGE, 1995). 
by Freud, dealing with sexual abuse in childhood and cases of shellshock following World War I. ${ }^{10}$

Herman expands on the impact of trauma on the human soul Traumatic ${ }^{11}$ events cast doubt on basic human relations (family, friendship, love, community), impair the faith in a natural or divine order, and the victim is caught up in an existential crisis that shatters the meaning of his life. Traumatic events harm man's autonomy first and foremost on the basic physical level. The body is wounded, weakened, desecrated. Sometimes, one loses control over one's body. On the mental level, the traumatic event causes a feeling of humiliation, as if the victim is deprived of his existence, nullified. This state leads to a feeling of shame in the face of helplessness, physical injury, and the disrespect shown by the offender. The feeling of shame is sometimes accompanied by feelings of guilt and inferiority. In this case, self-guilt acts as a mental survival mechanism, giving the victim a sense of rationality in light of feelings of irrationality and chaos caused by the traumatic experience. ${ }^{12}$

A person suffering from trauma will typically look for the closest and most available source of consolation. There are some who plead for divine deliverance, and when their pleas remain unanswered, they experience a religious crisis, a feeling of abandonment, and a loss of their basic truth. The feeling of abandonment embodies great loneliness. Amery relates in his book:

In the prisons and camps of the Third Reich, we scorned ourselves for being helpless and utterly weak, more than we bewailed our bitter fate. $^{13}$

Subsequently, he adds:

The experience of persecution was basically an experience of complete loneliness. What I ask is to be freed from the experience of abandonment, which has never left me since then. ${ }^{14}$

Similar feelings are described by Elie Wiesel in his book, "Night":

I will never forget those flames that forever extinguished my faith. I will never forget the silence of the night that forever robbed me of my desire to live. ${ }^{15}$

10 Christopher G. Frechette and Elizabeth Boase, "Defining 'Trauma' as a Useful Lens for Biblical Interpretation," in Bible Through the Lens of Trauma (ed. Elizabeth Boase and Christopher G. Frechette; Atlanta: SBL Press, 2010), 1-23 (3).

11 Judith L. Herman, Trauma and Recovery (New York: Basic Books, 1992).

12 Frechette and Boase, "Defining Trauma," 4-7.

13 Amery, Beyond Guilt, 136-148.

14 Amery, Beyond Guilt, 153.

15 Elie Wiesel, Night (New York: Hill and Wang ,1960), 43-44. 
The loss of faith merges with the endless depression. The trauma victim naturally strives to eliminate the traumatic event from his consciousness, but he is unable to do so. ${ }^{16}$ Because he is unable to express his experiences and feelings verbally, their expression generally becomes symptomatic. The difficulty of finding an outlet for the extreme anger results in uncontrollable outbursts of rage and extreme aggressiveness. ${ }^{17}$ Thus, instead of treating the root of the problem the traumatic experience that caused the hard feelings and the aggressive behaviour - attention is drawn to the symptoms, to the aggressiveness of the victim. This may impede treatment and rehabilitation. These and other symptoms are defined as "Post-Traumatic Stress Disorder" (PTSD), which is principally a memory-related syndrome. ${ }^{18}$ The normal mechanisms of consciousness and cognition are destroyed in the wake of traumatic experiences. Hence, the traumatic experience is not stored in the memory in a normal and proper way, resulting in the incapability of the victim to remember the traumatic event within the framework of his normal consciousness. Instead, the traumatic experience "haunts" him. The victim does not conceive the event as belonging to the past, but rather to the present, and he therefore experiences it in his consciousness over and over again. The American Diagnostic and Statistical Manual of Mental Disorders (DSM-V) lists four sub-categories of PTSD: ${ }^{19} 1$ :- Re-experiencing the traumatic event (recurring obsessive thoughts about the event, or a feeling that it is happening again). 2: Avoiding associations connected with the traumatic experience (avoiding thoughts or avoiding visiting places or meeting people related to the event). 3: Acute deterioration in mood in the wake of the traumatic event. 4: Hyperarousal symptoms, expressed in concentration difficulties, insomnia, and excessive nervousness.

The patient is clinically diagnosed as suffering from PTSD when the symptoms persist for more than a month and interfere with normal daily functioning. The symptoms may include "flashbacks," nightmares, disengagement (staring), depression, self-accusation, outbursts of rage or anxiety (sometimes violent), and anxiousness. When a person suffering from PTSD talks about the traumatic event he has experienced, he is not only talking about it but actually re-experiencing it.

Leys notes that the definition of the term "trauma" has changed substantially since its appearance towards the end of the $19^{\text {th }}$ century. ${ }^{20}$ Freud

\footnotetext{
16 Herman, Trauma and Recovery, 1.

17 Herman, Trauma and Recovery, 56.

18 Ruth Leys, Trauma: A Genealogy (Chicago: University of Chicago Press, 2000), 2. PTSD was introduced for the first time in DSM in 1980.

19 American Psychiatric Association, Diagnostic and Statistical Manual of Mental Disorders (Fifth Edition; Washington DC: American Psychiatric Association, 2013), 271-280.

20 Ruth Leys, From Guilt to Shame: Auschwitz and After (Princeton: Princeton University Press, 2007), 12.
} 
viewed the victim's identification with those who caused the trauma as a basic defence mechanism. ${ }^{21}$ The victim's feeling of guilt is connected to his urge to imitate the offender - to be as violent as him. Often, the victim behaves normally in the first years following the trauma, and only after he apparently has established himself, become rehabilitated, and settled down, post-traumatic symptoms such as nervous breakdown, depression, and outbursts of rage begin to appear.

As mentioned above, the experience of migration entails a great deal of stress and may lead to an identity crisis or identity change. The experience of migration, and especially of forced migration, contains traumatic elements such as separation, abandonment, loss, new conflicts, and the need for a speedy accommodation to a new reality, a new world. Berger and Weiss note that even voluntary migration is very likely to be traumatizing, and many emigrants define their emigration as the most difficult and traumatic experience of their lives. ${ }^{22}$ Berger and Weiss refer to the testimony of an Israeli physician who immigrated to the United States in her early forties: ${ }^{23}$

Being an immigrant means to turn from being somebody into being nobody and to fight for being somebody again...

According to Berger and Weiss, the process described here can be defined as "a loss of culture," including loss of physical, social, and cultural familiarity with the surroundings, as well as loss of language, framework of beliefs, and socioeconomic status. The situation becomes especially hard when no support from family or friends is at hand. Even in cases where the entire family unit emigrates, it often happens that each family member is preoccupied with his own personal struggle for survival and is mentally unavailable to assist other family members in their struggle. "Loss of culture" may develop into "culture shock," a mental response to the experience of migration including feelings of helplessness, insecurity, emptiness, meaninglessness, low self-esteem, confusion, disorientation, frustration, anger, and depression. The "culture shock" differs in accordance with the age and gender of the emigrant and, naturally, also in accordance with his personality structure, nature, and temper. For example, women tend to acclimatize more quickly than men, and children tend to develop cultural awareness and acquire new norms more quickly than adults. ${ }^{24}$ They become mediators between the new culture and their parents, and during the process they become exposed, at a young age, to many of the miseries in the world of the adults.

21 Leys, From Guilt to Shame, 18.

22 Roni Berger and Tzipi Weiss, "Immigration and Posttraumatic Growth - A Missing Link," Journal of Immigrant and Refugee Studies 1 (2002): 21-39.

23 Berger and Weiss, "Immigration," 23-24.

24 Berger and Weiss, "Immigration," 24. 
However, Berger and Weiss note that exactly this crucial and difficult stage carries potential for post-traumatic growth in the wake of the immigrant's successful coping with numerous hardships. When the immigrant recalls the immense mental powers he invested in coping with all the different stages of his migration, his self-esteem and self-confidence are strengthened, his worldview and philosophy of life change, and he acclimatizes better to his new environment. ${ }^{25}$ At this stage, the "here" and the "there" interchange in the immigrant's consciousness. ${ }^{26}$ The homeland is no longer defined as "here," but as "there," and is transformed from a living reality to a collection of memories. Ambivalence emerges in the consciousness of the immigrant ("homeland" against "new land"), the intensity of which determines the measure and speed of his integration in the new place.

Despite the potential for personal growth inherent in the migration experience, there are cases where the migration is liable to turn into an etiological cause of mental health problems, ${ }^{27}$ especially in the case of forced migration. ${ }^{28}$ For example, research conducted among Mexican immigrants in the United States showed that the frequency of PTSD is higher among the immigrants than in the general population. ${ }^{29}$ Birnbaum notes that national disasters or crises are liable to cause an increase in cases of PTSD, a phenomenon which is likely to express itself in a strengthening or radicalization of national feelings, violence, and national or religious instability. ${ }^{30}$

Berger and Weiss note that mental health problems may be a direct result of the migration experience. Alternatively, the migration may function as a trigger for the outburst of mental health problems or of conflicts between partners or family members, which had been present below the surface before the migration. There are a number of factors influencing the emergence of these problems and their intensity within the context of migration, such as family history or personal history of those coping with stress or crises in different areas of life (especially among adolescents and elderly people), the degree of difference between the "old" culture and the new culture, and the availability of family and friends who have already become integrated in the new land and may

25 Berger and Weiss, "Immigration," 27-29. See also Tedeschi and Calhoun, Trauma, 29-42.

26 Peter Kivisto and Vanja La Vecchia-Mikkola, "Immigrant Ambivalence toward the Homeland: The Case of Iraqis in Helsinki and Rome," Journal of Immigrant and Refugee Studies 11 (2013): 198-216.

27 Berger and Weiss, "Immigration," 24-25.

28 Mia Crager, et al., "Forced Migration and Psychotic Symptoms: An Analysis of the National Latino and Asian American Study," Journal of Immigrant and Refugee Studies 11 (2013): 299-314.

29 Peña, et al., "Traumatic Events," 38-39.

30 A. Birnbaum, "Collective Trauma," 534-535. 
function as mediators between the immigrants and the new culture. The immigrant's or refugee's set of beliefs is a crucial factor in determining the degree of success in coping with the migration experience. ${ }^{31}$ This set of beliefs is formed by a variety of factors, such as education, past experiences, family situation, legal status, and life conditions.

\section{TRAUMA IN THE BOOK OF EZEKIEL}

As I contended at the beginning of this study, the trauma of the Babylonian exile is the central axis around which the book of Ezekiel is constructed. Much pain and anger over the humiliation and contempt are embodied in this piece of literature. The fury and the violent feeling reflected in some of the prophecies in the book of Ezekiel brought Carley to the conclusion that it constitutes a preclassic kind of ecstatic prophecy. ${ }^{32}$ This literature character made various scholars attempt to understand the different figures and metaphors in the book of Ezekiel from various points of view. For example, in her extensive study of sexual and marital metaphors in biblical prophetic literature, Moughtin-Mumby's approach is literary-historical. ${ }^{33}$ According to Moughtin-Mumby, sexual and marital metaphors in biblical prophetic literature are a tool for illustrating the relationship between God and the people of Israel, especially in contexts of cultic infidelity to yhwh or relying on alliances with foreign nations, instead on yhwh's deliverance. $^{34}$

Another approach for analysing the unique prophetic style in Ezekiel is the psychological point of view. Schmitt claims that the book of Ezekiel contains the largest number of anomalies and psychological questions in proportion to the rest of biblical prophetic literature. ${ }^{35}$ The book contains some extremely strange figures, outrageously harsh, rough, and violent in nature - peaking in chapters 16,23 , which shall be discussed extensively below. ${ }^{36}$

The psychological exegesis, which aims to analyse the mind of the prophet/speaker in the book of Ezekiel emerged in the second half of the $19^{\text {th }}$

31 Francisco J. Eiorá Drasa, Michael Brune, Katrin Huter, et al., "Belief Systems as Coping Factors in Traumatized Refugees: A Prospective Study," Traumatology 17 (2011): 1-7.

32 Keith W. Carley, Ezekiel among the Prophets (London: S.C.M. Press ,1975), 6-8.

33 Sharon Moughtin-Mumby, Sexual and Marital Metaphors in Hosea, Jeremiah, Isaiah, and Ezekiel (Oxford: Oxford University Press, 2008).

34 Moughtin-Mumby, Sexual and Marital Metaphors, 1.

35 John J. Schmitt, "Psychoanalyzing Ezekiel," in Psychology and the Bible: A New Way to Read the Scriptures (ed. J. Harold Ellens and Wayne G. Rollins; vol. 2; Westport: Praeger, 2004), 185-201.

36 According to Darr, these texts in Ezekiel intended to shock listeners and readers. See Katheryn P. Darr, "Ezekiel's Justifications of God: Teaching Troubling Texts," Journal for the Study of the Old Testament 55 (1992): 97-117 (109). 
century and the beginning of the $20^{\text {th }}$ century, in the works of Klostermann $(1877)^{37}$ and Gunkel (1924). ${ }^{38}$ However already in 1930, as noted by Garber in his article, ${ }^{39}$ Torrey opposed this kind of exegesis and claimed that the "anomalous" behaviour and words of Ezekiel are no more than literary devices. ${ }^{40}$ Jobling claims that when reading the book of Ezekiel (and the Bible in general) preference must be given to the social-psychological analysis over the personalpsychological analysis. ${ }^{41}$ The trauma of exile stands at the centre of the book, and the assumption that chapters which are difficult to read, such as chapters 16, 23 , went through and survived the process of the Bible's editing and canonization (probably including some extent of censorship) shows that the Bible's editors as well as generations of readers identified with the feelings and messages of Ezekiel. Jobling adds the important point that every literary work combines the conscious with the subconscious, and every insight gained by the reader reflects first and foremost his own inner world and not necessarily the world of the author. Despite this criticism, scholars continued to attempt a definition of the mental pathology of the speaker in the book of Ezekiel, even scholars of later periods in the $20^{\text {th }}$ century. For example, in his article from 1946 Broome diagnoses Ezekiel to have suffered from Catatonic Schizophrenia and Paranoid Schizophrenia. ${ }^{42}$ In 1953, van Nuys analysed the stages in the process of prophesying, which in his opinion included a stage resembling schizophrenia, followed by catatonia. ${ }^{43}$ In 1993 Halperin published a comprehensive study on the psychological foundations of the book of Ezekiel, in which he analyses the mind of the prophet from a psychiatric point of view. ${ }^{44}$ Halperin's attempt was the last broad and comprehensive attempt to undertake a psychoanalytical analysis of the mind of the prophet Ezekiel. His attempt was met by staunch opposition from Bible scholars and psychologists alike. According to Kasher, the

37 August Klostermann, "Ezechiel: Ein Beitrag zu Besserer Wūrdigung seiner Person und seiner Schrift," Theologische Studien und Kritiken 50 (1877): 391-439.

38 Hermann Gunkel, "The Secret Experiences of the Prophets," Expositor 9, 1 (1924): 356-366, 427-433; Expositor 9, 2 (1924): 23-32.

39 David G. Garber, "Traumatizing Ezekiel, The Exilic Prophet," in Psychology and the Bible: A New Way to Read the Scriptures (ed. J. Harold Ellens and Wayne G. Rollins; vol. 2; Westport: Praeger, 2004), 215-235.

40 Charles C. Torrey, Pseudo-Ezekiel and the Original Prophecy (New Haven: Yale University Press, 1930).

41 David Jobling, "An Adequate Psychological Approach to the Book of Ezekiel," in Psychology and the Bible: A New Way to Read the Scriptures (ed. J. Harold Ellens and Wayne G. Rollins; vol. 2; Westport: Praeger, 2004), 203-213.

42 Edwin C. Broome, "Ezekiel's Abnormal Personality," Journal of Biblical Literature 65 (1946): 277-292.

43 Kelvin van Nuys, "Evaluating the Pathological in Prophetic Experience (particularly in Ezekiel)," Journal of Bible and Religion 21 (1953): 244-251.

44 David J. Halperin, Seeking Ezekiel: Text and Psychology (University Park: Pennsylvania State University Press, 1993). 
symbols used by the prophet in his prophecies do not reflect any mental state; rather they represent religious, social, and cultural aspects. ${ }^{45}$ Also, Daschke notes, in his article, that no conclusions concerning the mental state of the prophet can be deduced from reading his book, only conclusions concerning the feelings of the speaker, who feels anger and grief in the face of the loss of his homeland, and longs for it.The fantasies of Ezekiel express his grief and ${ }^{46}$ function as a way of coping with the loss. For example, the Vision of the Chariot in chapters 1-2 constitutes Ezekiel's attempt to cope with the feeling of having been abandoned by God, thus he envisions God as going into exile from Jerusalem to Babylon together with Ezekiel and his community.

As stated above, many of Ezekiel's prophecies are strange and grotesque in nature. Following the breath-taking Vision of the Chariot in chapters 1-2, Ezekiel consumes "a scroll of a book" given to him by God (2:8-3:3), is commanded to lie on his left side for 390 days and then forty more days on his right side (4:4-8), commanded to bake his food on human excrement (4:9-17), to shave his hair and beard, to divide the hairs into three, to burn one third of them, to slay the other third with the sword, and to scatter the last third with the wind (5:1-4). Very often he falls on his face, or pleads before God, and the spirit of God takes him to different places. However, the peak of the sexual and violent grotesqueness is reached especially in two chapters: 16 and 23 .

Chapters 16 and 23 are both structured according to a pattern of three main stages: building of tension (16:1-35; 23:1-21), violent outburst (16:36-58; 23:22-35), and tranquillity (16:59-63; 23:36-49). However, attention should be payed to the differences between the two narratives ${ }^{47}$ Chapter 16 deals with a single woman, while chapter 23 deals with two sisters. In addition, chapter 16 concentrates on cultic offences, while chapter 23 focuses on political crimes. In spite of the obvious resemblance and similarities between the two chapters, each one should be discussed separately and be viewed as a unique literary unit within a larger composition. Hence, within the framework of the present study, I will focus on the literary analysis of these two chapters and the ways in which they present the trauma and the post-trauma of the speaker, who functions as a rare explicit "exilic" voice of his generation. Likewise, I shall expand on the issue of the muteness and the lying on the side $(3: 22-27 ; 4: 4-8)$, which is relevant to the discussion.

45 Rimon Kasher, Ezekiel (Miqrā’ lěyiśrāàēl; vol. 1; Tel Aviv: 'Am' Oved, 2001), 910.

46 Dereck M. Daschke, "Desolate among them: Loss, Fantasy and Recovery in the Book of Ezekiel," American Imago 56 (1999): 105-132.

47 Moughtin-Mumby, Sexual and Marital Metaphors, 157. 


\section{$1 \quad$ Ezekiel 16}

Ezekiel 16 is, from the point of view of its descriptions, expressions, and emotions, one of the most theologically challenging as well as linguistically and rhetorically biting chapters in the Bible. Scholars have defined this chapter, together with chapter 23, as "pornography" and characterized Ezekiel as a sexual pervert with misogynistic inclinations and a deep contempt for female sexuality. ${ }^{48}$ This chapter even seems to have been a matter of dispute between the scholars of the Talmud, since R. Eliezer ruled that chapter 16 must not be read as haphtarah. ${ }^{49}$

The chapter begins with a divine command to Ezekiel: "Son of man, make known to Jerusalem her abominations" (v. 2), but instead of providing an explicit and orderly list of sins, God relates an allegorical tale in which Jerusalem is anthropomorphized as a woman between whom and God, "the man," a fatherlyromantic relationship develops. The personification of Jerusalem as a female, the spouse of the male God, is common in the prophetic books of the Bible (see Isa 1:21; Jeremiah 2; Hosea 1-3), as is also the fatherhood of God in relation to the people of Israel (for example, in Isa 1:2, 4). However, in Ezekiel 16 a different and not clearly defined relationship seems to develop between God and Jerusalem.

First, God describes the ethnic origin of the city of Jerusalem - her being the daughter of an Amorite father and a Hittite mother. This Canaanite origin fits the fact that Jerusalem was a Jebusite city before it was conquered by David. Already at this initial stage, criticism is levelled at the inhabitants of Jerusalem, who are compared to Canaanites, with all the implied theological and moral implications.

Immediately upon her birth, Infant Jerusalem was abandoned by her parents and thrown into an open field without receiving even the most basic care (vs. 4-5): the umbilical cord and the placenta were not cut; she was neither washed in water, nor rubbed with salt or disinfecting oils, nor wrapped in cloths. She was treated cruelly, apparently in order to kill her. Galambush calls attention to the blood of Jerusalem (as well as her foreign origin) as a symbol of impurity - a central motif in the priestly thought with which Ezekiel identifies. ${ }^{50}$ At this

48 E.g. Halperin, Schmitt, and also Zucker and Reiss: David J. Zucker and Moshe Reiss, "Ezekiel as Misogynist," Biblical Theology Bulletin 46 (2016): 186-190.

49 Megillah 4:10. According to bShab. 13b, "its [the book of Ezekiel] words contradict the words of the Torah," and only thanks to the reconciliations of Hananiah son of Hezekiah was the book of Ezekiel not excluded from the Canon.

50 Julie Galambush, Jerusalem in the Book of Ezekiel: The City as Yahweh's Wife (Atlanta: Emory University, 1992), 91-106. 
initial stage, Jerusalem is presented as a victim, as vulnerable and fragile, a description which later on is to be turned upside down. ${ }^{51}$

Verses 6-14 describe how God, apparently by chance, finds Jerusalem wallowing in her blood (v. 6: "I passed by you and saw you..."). Through the utterance "and I said to you as you lay in your blood: Live!" God sentences Jerusalem to life, takes care of her, and saves her life (without expressing any kind of special sympathy or explicit compassion). Then, in a single verse, the baby grows up and turns into a sexually mature, and still naked, young woman (v. 7). It is not clear whether God has raised her as his daughter, or only saved her life and provided her with her basic needs. In verse 8, God again passes by her accidentally and notices her being a naked mature young woman, the impression being that they are not intimate. ${ }^{52}$ Also at this stage, when God notices the young woman, swears to her, and enters a covenant with her, no feelings are described, only a matter-of-fact like report about the breath-taking clothing and jewellery that God grants Jerusalem his bride.ate description of The elabor ${ }^{53}$ God's devoted treatment towards Jerusalem and the gift showering emphasizes Jerusalem's ungratefulness in her maturity. ${ }^{54}$

Jerusalem turns into a beautiful young woman who owes her life to God, with whom she has entered into a covenant. However, the allusion to the Canaanite origin of Jerusalem with which the story commenced, pre-determines her behaviour and fate. She betrays God, her saviour and husband, and commits adultery with every passer-by from all the nations of the region, who have heard about her beauty. She sleeps with them on the high places she has raised (v. 16), spends the silver and gold God has given her to make "male images" (perhaps intended for masturbation). She worships these images and sacrifices to them of the choice food God has given her (vs. 18-19); in accordance with the custom of the Canaanites, she also sacrifices the children that she has borne to God, and with even greater cruelty - she has consumed them (vs. 20-21). At this stage, God provides a lengthy description of the severe sins and crimes of Jerusalem, momentarily without harming her. The reckless behaviour of Jerusalem is a

51 Cooke identifies in these verses the folk story motif of finding a baby and saving it (like the story of the birth of Moses). See George A. Cooke, A Critical and Exegetical Commentary on the Book of Ezekiel (ICC; Edinburgh: T \& T Clark, 1951), 159.

52 Kamionkowski, relying on Ruth 3:9, conjectures that the expression "to spread the edge of the garment" in verse 8 is a euphemism for sexual relations, the spreading of the garment meaning to take it off. See S. Tamar Kamionkowski, Gender Reversal and Cosmic Chaos: A Study on the Book of Ezekiel (JSOT Supp. 368; London: Sheffield Academic Press, 2003), 107.

53 Cf. also the emotionally loaded description in Isa 54:7-8: "... For a brief moment I deser-ted you, but with great compassion I will gather you. In overflowing anger for a moment, I hid my face from you, but with everlasting love I will have compassion on you..."

54 Darr, "Ezekiel's Justifications of God," 105. 
source of embarrassment even to her enemies, the daughters of the Philistines (v. 27). The sexual appetite of Jerusalem is insatiable. She commits adultery with Egyptians, Assyrians, Canaanites, and Chaldeans (vs. 28-29). As the descriptions become more and more explicit, the divine anger also becomes more felt along the text. After the rather dry description of adultery and brutality in verses 1521, the speech of God becomes more admonishing, focusing on the unfaithfulness and ingratitude of Jerusalem towards Him (v. 22: "And in all your abominations and your prostitution you did not remember the days of your youth, when you were naked and bare, wallowing in your blood"), ${ }^{55}$ until the anger gradually increases (v. 23: "Woe woe unto you"), as preparation for the punishment to be imposed on Jerusalem.

In verse 36 , the section dealing with the punishment of Jerusalem begins.

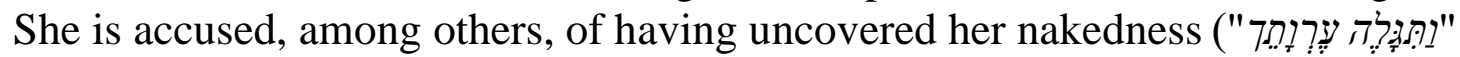
, an expression found mainly in the Book of Holiness (Leviticus 17-26) and in the book of Ezekiel, ${ }^{56}$ meaning to reveal one's genitals. Rozen-Tzvi points out that the expression serves as a metaphor for forbidden sexual relations that entail "the encroachment of [the husband's] privacy."57 In contrast to Talmudic Hebrew, where the expression refers to forbidden sexual relations between relatives, in the book of Leviticus the expression refers to forbidden intercourse. However, it seems that in Ezekiel 16, the expression ערוה is ambiguous, it means both revealing one's nakedness in public as an expression of prostitution (v. 36), and the primordial, innocent, and pure state of nakedness of infant Jerusalem, whom God has saved from death (vs. 7-8, 22).

After being sexually autonomous and brazen (v. 30: "The deeds of a brazen prostitute"), Jerusalem is now submissive before the furious, betrayed, and humiliated husband, who has long suffered from the actions of His spouse. God, who in this chapter fills the role of victim, accuser, and judge, assembles all the lovers of Jerusalem and uncovers her nakedness before them. This action, which previously had been carried out willingly by sinning Jerusalem, now turns into a humiliating punishment, according to the principle of "measure for measure." God is the victim of the deeds of Jerusalem, but He also functions as her judge. He judges her "as women who commit adultery and shed blood are judged" (v. 38), and delivers her into the hands of her former lovers, who lynch her. The violence and fury reflected in these verses are extremely tangible. Jerusalem is beaten, her high places are ruined, she is undressed, and her beautiful clothes are taken away. The circle is closed when she returns to her former state of being "naked and bare" (v. 39), like in her childhood. The mob

55 As an antithesis to Jer 2:2: "... I remember the devotion of your youth, how as a bride you loved...".

56 Also in Exod 20:22; Isa 47:3.

57 Ishay Rosen- Zvi, The Mishnaic Sotah Ritual: Temple, Gender and Midrash (Hebrew version; Jerusalem: Magnes, 2008), 186-189. 
stones her and cuts her into pieces with swords (v. 40). They burn down her houses, carrying out the retribution in front of a whole crowd of women (perhaps in order to make an example). Only after the violent ecstasy has cooled down is God finally appeased (v. 42). At this stage, the prophetic discourse becomes (relatively) more moderate and stabilizes itself on the normal rhetorical level.

Samaria and Sodom are mentioned as the sisters of Jerusalem (v. 46), a motif further developed in chapter 23. Jerusalem is the most sinful of the three sisters (vs. 49-51), even though Sodom is the biblical symbol of evil and wickedness (see Isa 1:10; 3:9; Jer 23:14; Lam 4:6). At the end of the chapter, God uses his forgiveness of Jerusalem as a way of punishing her: $\mathrm{He}$, the betrayed victim, will eventually forgive her, even though she has broken her covenant with Him. However, this forgiveness serves a purpose: "So that you may remember and be ashamed and never open your mouth anymore because of your humiliation..." (v. 63). Thus, the intensity of the fury and aggression hardly cools down throughout the entire chapter, not even in its end.

\section{Ezekiel 23}

There is a strong resemblance between chapters 16 and 23. The focus of both chapters is Jerusalem's (the wife) betrayal of God (the husband) and the struggle between them. While chapter 16 opens with a certain tone of gentleness compassion towards the baby that had been abandoned at birth, - chapter 23 opens with an accusation of adultery against Jerusalem already in verse 3 . Jerusalem (Oholibah) and Samaria (Oholah) are two sisters who are married to God. They betray him with lovers from different nations. ${ }^{58}$ Oholah (Samaria) lusts after the Assyrians and the Egyptians, ${ }^{59}$ who are described as horsemen dressed in their uniforms, wherefore she is punished (vs. 9-10) by being humiliatingly undressed by her Assyrian lovers ("they uncovered her nakedness"receiving her just retribution. Her younger sister, Oholibah (Jerusalem) does not learn the lesson from the fate of Oholah, and "her whorings were worse than the whorings of her sister" (v. 11). She lusts for the Assyrians - governors, rulers, officials, and horsemen dressed in colourful uniforms, whose images she sees carved on the wall (v. 14). Likewise, she lusts for the Babylonians, who desecrate Jerusalem with "their harlotry" (v. 17), until she has had enough of them. Also, God has had enough of Jerusalem, in accordance with the principle of "measure for measure" (vs. 18, 22). ${ }^{60}$ God summons the "lovers" of Jerusalem, who will

58 The root זנז appears 21 times in the chapter (comprised of 49 verses).

59 The root עגב refers to sexual desire, and appears in the Hebrew Bible only in Ezek

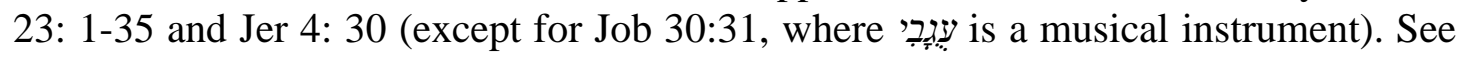
Moughtin-Mumby, Sexual and Marital Metaphors, 195.

60 The meaning of the biblical expression נפש + ניקע is a sense of repulsion and abhorrence, see David J. A. Clines et al., "קע," The Dictionary of Classical Hebrew 4: 274. 
judge her with God's authorization (v. 24). They will attack Jerusalem with fury, cut off her nose and ears, undress her, rob her of her fancy tools; they will cut down her remnant with the sword and burn it with fire. ${ }^{61}$ It is possible that verse 34 contains a reference to the tearing off of the breasts of Jerusalem ("... and you shall break the sherds thereof, and tear off your own breasts..."). After the elaboration of the sins and abominations of Jerusalem and Samaria, including different kinds of foreign worship, human sacrifices, desecration of the Sabbath, and defiling of the temple (within the framework of the political loyalty of the kingdoms of Samaria and Judah towards great powers such as Assyria, Egypt, and Babylonia, the foreign cults were introduced into their shrines), "righteous people" (v. 45) will arrive and judge Oholah and Oholibah. ${ }^{62}$ They will be judged "like adulterous women are judged," and the crowd will stone them, slay their sons and daughters with the sword, and burn their houses down with fire. In the wake of this, all women will learn the lesson, and there will be no more lewdness throughout the land (v. 48).

Like in chapter 16, the intensity of the fury and the sentiments increases gradually and reaches an ecstatic peak of unrestrained violent revenge on sinful, adulterous, unfaithful Jerusalem, who has humiliated God in the eyes of the nations and broken her covenant with Him. Galambush points out that while chapter 16 focuses on the blood and nakedness of Jerusalem (as objects of impurity), chapter 23 emphasizes her sexual perversion. ${ }^{63}$ In contrast to chapter 16 , where Jerusalem is considered innocent during her youth, before she commits adultery, chapter 23 describes Jerusalem as corrupt already in her youth, characterized by an animal-like, inhuman sex drive (v. 20).

In v. 38 appears the accusation of the defiling of the temple (v. 38). Ezekiel 8 mentions the conduct of foreign rites in the temple in Jerusalem, amongst others women weeping for Tammuz (v. 14), and the worship of the sun (v. 16), which may have been of Egyptian origin. From here it can be inferred that the "political prostitution" of Judah, which replaced political faithfulness, also included "religious prostitution." In his extreme wrath, Ezekiel describes the relations of Judah with the great powers in a sexual-metaphorical, humiliating, and violent manner.

It seems that in chapters 16, 23 "adulterous" Jerusalem receives her due punishment in accordance with biblical law as it is reflected in Deut 22:22 - the death penalty. However, the way Jerusalem is put to death in chapters 16, 23

61 The word אחרית here means "remnant" (and not "end"), those who initially survived but, in the end, suffered a violent death. See David J. A. Clines, et al., "אחרית," The Dictionary of Classical Hebrew 1: 201; Ludwig Koehler and Walter Baumgartner, "אחרית," The Hebrew and Aramaic Lexicon of the Old Testament 1: 158.

62 Notice the resemblance to 16: 38.

63 Galambush, Jerusalem in the Book of Ezekiel, 109-125. 
appears anomalous and melodramatic (or maybe "theatrical"). It includes elements of bodily corruption, public humiliation, and the destruction of the belongings and property of the adulterous woman. Rozen-Tzvi examines this issue in the light of Ancient Near Eastern laws dealing with adultery. ${ }^{64}$ Like in the Torah, also in many other Near Eastern cultures, adultery was punished by death, although the punishment does not seem to have been carried out in the public and melodramatic way it is described in Ezekiel 16, 23. According to paragraph 129 in the law code of Hammurabi and paragraph 15 in the Assyrian Law, a husband is allowed to pardon his adulterous wife or to change her punishment (apparently into divorce). However, the Assyrian Law resembles the description in Ezekiel inasmuch as the husband has the right to cut off his wife's nose (Ezek 23:25) instead of killing her. According to the book of Ezekiel he is allowed to do this in addition to killing her. The Near Eastern laws of divorce resemble to a certain extent the description in Ezekiel, especially the confiscation of the woman's clothes and leaving her naked (see Hos 2:11-12, and also Nah 3:5-6). Communal humiliation and public undressing of prostitutes existed as a social custom, although they were not anchored in any law. The Sumerian text Nippur Trial (IM28051), the deciphering of which is made difficult by the fact that only parts of it have survived, describes (according to one interpretation of the text) the fate of an adulteress, including public humiliation, exposure and corruption of her body.

As mentioned, the biblical law in Deut 22:22 sentences an adulterous woman to death. However, Jer 3:8 seems to indicate the existence of an alternative punishment: divorce. The description of the fate of the adulteress in Ezekiel is harsher than the descriptions found in Hosea 2 and Nahum 3 (perhaps Ezekiel combines a number of different punishments customary in Israel and other cultures between the $8^{\text {th }}$ and the $6^{\text {th }}$ centuries B.C.E.). One must keep in mind that according to the ideology of the book of Ezekiel, murder, idol worship, and adultery are the gravest sins (in addition to Ezek 16:38; 23:45, see also Ezek $18: 6-10 ; 22: 3,9 ; 33: 25-26)$.

Day compares the behavioural pattern of God towards Jerusalem to a husband who behaves violently towards his wife. ${ }^{65}$ God hurls a number of very harsh and hateful sexual accusations at Jerusalem (16:15-17, 25-26, 28-31, 36), and his personality has a dual component: one of his hands caresses (vs. 6-14, 59-63) while the other one beats (vs. 37-43). The violence towards Jerusalem is sexual in nature, like the exposure of the genitals and the corruption of the breasts $(16: 37,39 ; 23: 34)$. Day also identifies the characteristic behaviour of a violent

64 Rosen-Tzvi, Sotah Ritual, 196-202.

65 Linda Day, "Rhetoric and Domestic Violence in Ezekiel 16," Biblical Interpretation 8 (2000): 205-230. 
husband in the comparison of Jerusalem with other unfaithful female family members (16:45-56).

In her book, Kamionkowski presents an interesting theory on chapters 16, 23, which has the potential to enhance our understanding of the mental state of the author and his community. ${ }^{66}$ According to Kamionkowski, Ezekiel 16 contains a gender reversal which is based on the experience of being exiled. In the beginning of the chapter, Jerusalem is passive and "feminine." However, subsequently and throughout most of the chapter she becomes active and independent, and therefore - "masculine." Her violation of the covenant is tantamount to the violation of the natural cosmic order, in which the male is active and dominant while the female is passive and submissive. The author finds the unstable nature and behaviour of Jerusalem deserving of condemnation. Perceiving a city as a woman is not unique to the Bible, since in Mesopotamian cultures and in ancient Greece the city was known to be perceived as a goddess. ${ }^{67}$ However, the perception of a city as an adulteress is still known only from the Bible.

It seems that the trauma of exile caused, amongst others, a change in gender related conceptions and norms among the exiles in Babylon. Numerous researches on the experiences and testimonies of male soldiers during war indicate experiences of emasculation. ${ }^{68} \mathrm{~A}$ similar phenomenon can be discerned in written curses from across the Ancient Near East, which attribute female characteristics, weakness, and shame to soldiers who have lost in battle. ${ }^{69}$ In these societies, the dichotomy "honour-shame" parallels the dichotomy "manwoman." 70 An example of this is found in 2 Sam 10:4-5, where Hanun king of Ammon ordered to shave the beards and cut the garments of David's servants "to the buttocks" in order to humiliate, shame, and scorn them. And indeed, the servants of David "were greatly humiliated" and were forced to stay in Jericho until their beards grew back. Also, in Mesopotamia the exposure of nakedness symbolized vulnerability and extreme humiliation. Esarhaddon boasts that he had restored the honour of war captives by providing them with clothes. ${ }^{71}$

Hence, in the book of Ezekiel the trauma of the exile is expressed through passivity, which has traditionally been identified with femininity. Ezekiel appears as a passive character in many places in the book, such as in the pericope of the eating of the scroll (Ezekiel 3), or when God seizes him like a doll and

66 Kamionkowski, Gender Reversal.

67 Kamionkowski, Gender Reversal, 23-24.

68 Kamionkowski, Gender Reversal, 61.

69 Kamionkowski, Gender Reversal, 28 (see Jer 30:5-6; 48:41; 49:22; 50:37; Isa 19:16).

70 A number of biblical roots are related to shame: בוש, כלמ ,קלה, תפר , See Johanna Stiebert, "Shame and Prophecy: Approaches Past and Present," Biblical Interpretation 8 (2000): 255-275.

71 Kamionkowski, Gender Reversal, 61-67. 
moves him from place to place with His hand or His wind $(2: 2 ; 8: 3 ; 11: 1,24$; 37:1). Likewise, in the pericope of Ezekiel's lying tied with ropes (4:4-6), the shaving of his hair (5:1-4), and God's making him mute (3:26). In a few cases Ezekiel opposes or has reservations about God's deeds (9:8; 11:13), in contrast to the prophet Jeremiah (cf. Jer 20:7-18). However, according to Kamionkowski, often when a man feels that his masculinity (that is, his honour) is threatened, he will typically compensate for this through exaggerated stereotypical "masculine" behavior, including the display of aggression and self-confidence. This kind of behavior may sometimes entail a violent and humiliating attitude towards women. In chapters 16, 23, Ezekiel, in his role as the embodiment of the community of the exiles, turns the humiliation and downtrodden honour of the exiles into violence towards the City-Woman Jerusalem. He now speaks in the name of God, the furious man, and in this way he feels that he is in control and restores the lost honour. The humiliated turns into humiliating as a way of coping with the trauma he has experienced..$^{72}$ It is important to note that Kamionkowski qualifies her analysis by emphasizing that it is wrong, perhaps impossible, to analyse the psychological state of mind of the author of Ezekiel 16, 23. The analysis is literary and based on the historical background. The text does not necessarily represent the author's personal mental state of mind; it only provides an opportunity for understanding the state and feelings of his community, for whom his words were intended. ${ }^{73}$

Jerusalem's punishment restores the natural order, and the experience of exile receives positive meaning through its rehabilitating and purifying effect. The exiles were chosen by God for punishment, but also for a positive renewal of the relations between God and the nation. The primordial state is restored, like in Ezek 16:4-14 where young and innocent Jerusalem enters a covenant with God. According to Darr, Ezekiel 16, 23 are texts of Theodicy. God's wrath and harsh treatment of the people of Israel are justified by the appallingly elaborate descriptions of the people's deeds (both Jerusalem and Samaria). The harshness of the deeds justifies the intensity of God's response. ${ }^{74}$

\section{The muteness and the lying on the side (Ezek 3:22-27; 4:4-8)}

In chapter 3:22-27, Ezekiel witnesses "the honour of God" in the valley, similarly to the honour that was revealed to him by the river Chebar $(1: 1,3)$. The prophet falls on his face, but "a wind" gets him to his feet. God orders Ezekiel to shut himself up in his house, and there he will be tied with "ropes" and his tongue will stick to the roof of his mouth so that he will become mute and unable to serve as "an admonisher" to his people, "for they are a rebellious house." Only when God decides to open the prophet's mouth will he transmit the words of God.

\footnotetext{
72 Kamionkowski, Gender Reversal, 67-73.

73 Kamionkowski, Gender Reversal, 78.

74 Darr, "Ezekiel's Justifications of God."
} 
Additionally, in chapter $4: 4-8$, the prophet is commanded to lie on his left side

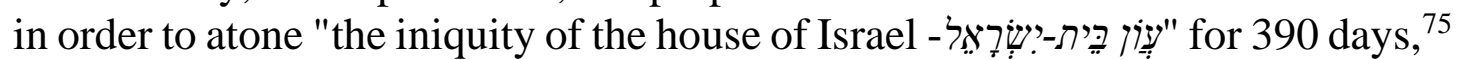
and then to lie on his right side to atone "the iniquity of the house of Judah" for forty days (v. 6: "I have assigned you each day for a year"). ${ }^{76} \mathrm{He}$ shall lie this way while facing "the siege of Jerusalem" (possibly a reference to the model of the city of Jerusalem and the Babylonian siege of it that Ezekiel was commanded to build in vs. 1-3 of the same chapter).

These two sections entail a number of literary and logical difficulties. ${ }^{77}$ There is an apparent contradiction between Ezekiel's assignment as a prophet (2: 3-7), and his muteness (3:26). Two main suggestions arose for explaining this difficulty: A psychological explanation and a symbolic one. ${ }^{78}$ Davis sees the swallowing of the scroll and the subsequent muteness of Ezekiel as symbolic and representing the literary-historical changes in ancient Israelite traditions, from orally to textually delivered. According to Davis, this process began in the eight century B.C, and reached its peak in Ezekiel's time. ${ }^{79}$ Textualizing the prophetic traditions made it possible to interpret them simultaneously, and in that sense, Ezekiel describes and interprets the ancient Israelite tradition according to his own point of view. Davis interprets the silence of Ezekiel as the silence of God shortly after the first deportation to Babylon (597 B.C.E.). God has nothing to add to all his recent warnings and calling for repentance. The punishment speaks for itself. ${ }^{80}$ When the refugee from Jerusalem arrives in Babylon and tells about the catastrophic destruction of the city (33:21-22), Ezekiel's muteness ends, and new messages can be delivered from God to the People of Israel. ${ }^{81}$

Davis's theory avoids some problematic issues in the text. According to the chronological description in the book of Ezekiel, the muteness lasted from the $12^{\text {th }}$ of Tammuz 593 B.C.E. (according to the dates registered in 1:1-2 and

75 According to Cooke, "the house of Israel" in v. 4 refers to the kingdom of Israel, since the left side symbolizes the North. In contrast, "the house of Judah" in v. 6 refers to the kingdom of Judah. See Cooke, Ezekiel, 51-54.

76 According to the Septuagint, 150 days on the left side and 40 days on the right side. A total of 190 days.

77 For an extended discussion of these difficulties, see Moshe Greenberg, "On Ezekiel's Dumbness," Journal of Biblical Literature 77 (1958): 101-105; Robert R. Wilson, "An Interpretation of Ezekiel's Dumbness," Vetus Testamentum 22 (1972): 91104; Ellen F. Davis, "Swallowing Hard: Reflections on Ezekiel's Dumbness," in Signs and Wonders: Biblical Texts in Literary Focus (ed. J. Cheryl Exum; Atlanta: Scholars Press, 1989), 217-237.

78 Davis, "Swallowing Hard," 218.

79 Davis, "Swallowing Hard," 224.

80 Davis, "Swallowing Hard," 228-230.

81 Davis, "Swallowing Hard," 232. In a response to Davis's theory, Darr interprets the swallowing of the scroll as a counter-argument of the prophet to potential claims/ accusations of false prophecy. See Darr, "Ezekiel's Justifications of God." 
3:16) until the $5^{\text {th }}$ of Tevet 585 B.C.E. (on the basis of 33:21-22, where the prophet opens his mouth and ceases to be mute), that is to say, a period of seven and a half years, during which we find a whole series of public prophecies (see $11: 25 ; 14: 1 ; 20: 1)$. Greenberg notes that many scholars think that the muteness appeared alternately or symbolically (for short periods of time). In his opinion, though, it was continuous; however, it was restricted to day-to-day speech and did not include delivering the word of God to the elders and dignitaries who visited him in order to seek the guidance of God. In this context, Wilson raises an additional difficulty: is it plausible to assume that the prophet was commanded to keep his silence immediately upon his dedication as a prophet? According to 3:26, the command to remain mute serves a specific purpose - to prevent Ezekiel from reproving the rebellious people. Only after Jerusalem's complete and final downfall, when the refugee arrives in Babylon and relates the fate of the city and its temple, does God open the mouth of the prophet. This seems to contradict both the general mission of Ezekiel to serve as a watchman who warns about the impending punishment, as well as the existence of numerous prophecies from the period before the destruction of Jerusalem in chapters 4-23. A possible explanation for this is that the section in 3:22-27 originally belongs to a later chapter - perhaps chapter 24 or chapter 33 (as suggested by Sterane, Davidson, May). Wilson rejects the possibility that the muteness was only symbolic, since in chapter 24:27 its removal is defined as "a sign - מוֹפת " which in his opinion shows that the muteness must have been real. The present location of the section in 3:22-27 possibly reflects editorial considerations surrounding the process of the book's formation - to create a frame for chapters 3-33. Wilson views 3:2227 as part of the extended vision of dedication with which the book begins.

According to the plain meaning of $3: 26$, the mute prophet does not

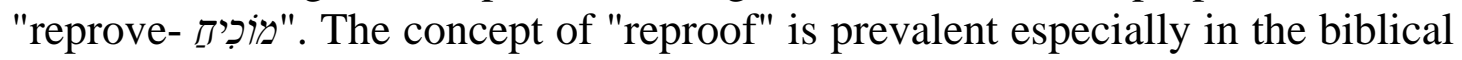
wisdom literature (see Prov 9:7; 24:25; 25:12; 28:23). In legal contexts, the root יכח parallels the root ריב, and it seems to refer to a person who participates in trials making sure that the legal process is conducted according to the principles of justice and truth (see Job 9:33; 32:12; Isa 2:4; 11:3-4; Micah 4:3). According to Wilson, the secondary meanings of the root יכח-moral reproof, words of fury, and warning about future punishment - are later developments. Hence, the muteness of Ezekiel reflects the fact that God has forbidden the prophet to serve as mediator between Him and the people. He must therefore remain locked up in his house (and not sit, for example, in the city gate, where trials were conducted), so that he will not be able to represent the people before God. He is only allowed to inform the people about the expected punishments. As soon as the punishment is carried out and Jerusalem is destroyed, the muteness is revoked and the prophet will serve as the people's advocate and mediate between them and God. This can be proven from the fact that from chapter 3 to the downfall of Jerusalem, Ezekiel speaks only about the destruction of the city. 
Commentators have suggested two main interpretations of the term in in in the context of Ezekiel's lying down on his side. One interpretation views the period of lying as symbolizing the years of sin, while the other interpretation views the lying as referring to the years of punishment. Keil and Eichrodt subscribe to the first opinion and understand the number of years as symbolic only, like the act of lying itself. Greenberg, in contrast, subscribes to the ${ }^{82}$ second interpretation. ${ }^{83}$ In the Bible, he claims, the left side carries negative connotations. ${ }^{84}$ Ezekiel plays a double role in his book: prophet and priest. As a priest he atones for the sins of the people by "suffering" the punishment on their behalf. ${ }^{85}$ To this physical suffering the tying with ropes and muteness are added, which are mentioned in both 3:25 and 4:8 (wherefore Cook assumes that the section in Ezek 4:4-6 was originally placed between 3:24 and 3:25).

The forty years of punishment resemble God's punishment of the people after the sin of the spies (Num 14:34). The 390 years possibly symbolize the estimated number of years of the first temple. The Septuagint attests the number 150 years, which may refer to the length of the exile of the kingdom of Israel (which was exiled 110 years before the exile of Jehoiachin) together with the forty years of the exile of Judah, two exiles that would end at the same time (Ezek 37:15-28). The "orderly" version of the Septuagint is hardly original. Cassuto and Friedman noted the resemblance between the section in the Septuagint and the story of the Flood: forty days of rain and 150 days during which the waters covered everything (Gen 7:12, 24). ${ }^{86}$ Kasher sees a connection between verse 4 and the pericope of the scapegoat in Lev 16:21-22, although in the case of Ezekiel the iniquities of the people are not transferred to him; rather, the symbolic act he carries out (lying tied and being mute) is a symbolic expression of the way the people will bear its punishment - unsovereign and weak (or the way it ought to bear its punishment - in silence and obeisance). ${ }^{87}$

The differences between the combinations עון + עון + עים in verse 4, נעון in verses 5-6, and נעון + עשא in verses 4-6, may contain an important key to

82 Carl F. Keil, Biblical Commentary on the Prophecies of Ezekiel (Grand Rapids: W.B. Eerdmans, 1950), 71-78; Walther Eichrodt, Ezekiel (OTL; London: SCM Press, 1970), 83-86.

83 Moshe Greenberg, Ezekiel 1-20 (AB; Garden City: Doubleday, 1983), 104-106.

84 See Eccles 10:2: "The heart of the wise inclines to the right, but the heart of the fool to the left." And by way of negation, cf. the positive meaning that the bible attributes to the right side (Gen 48:17; Ps 137:5).

85 Block finds it noteworthy in this context that in verse 4 the root שימ connection with the term עון, while in verse 6 the root appears, as it usually does in the context of atonement for sin. See Daniel I. Block, The Book of Ezekiel: Chapters 124 (NICOT; Grand Rapids: W. B. Eerdmans, 1998), 175-180.

86 Moshe D. Cassuto, From Noah to Abraham (Hebrew; Jerusalem: Magnes, 1959), 67.

87 Kasher, Ezekiel, 197-198. 
understanding the words of Ezekiel in verses 4-6. The most prevalent of these phrases is עון + נשא, which appears 36 times in the Bible, most of them in the priestly literature of the Pentateuch (Leviticus and Numbers). The combination appears only twice: Ps 69:28 (עון + נתנ

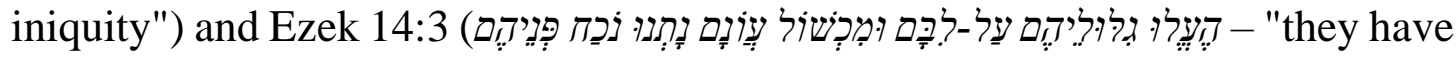
set up idols in their hearts and have put sinful stumbling blocks before their

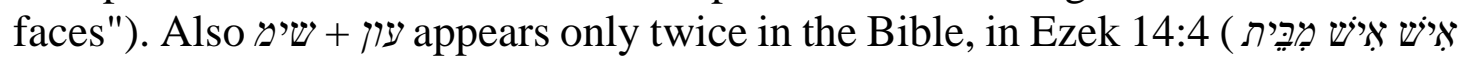

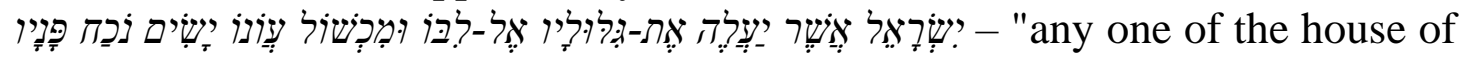
Israel who takes his idols into his heart and sets the stumbling block of his

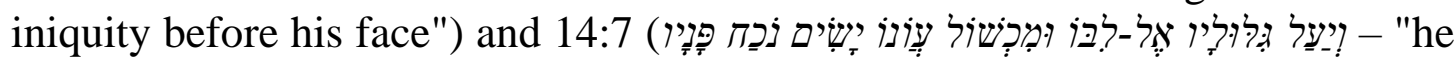
sets up his idols in his heart, puts right before his face the stumbling block of his

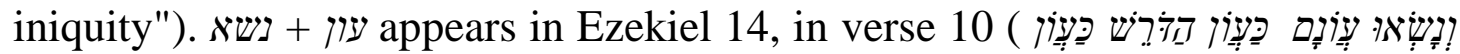

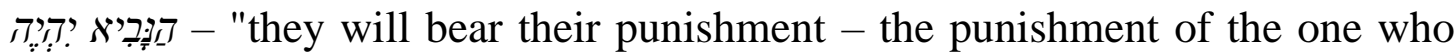
inquires will be the same as that of the prophet"). In the section in chapter 14 under discussion the prophet deals with the elders of the Babylonian exiles, who seek to inquire with God through Ezekiel. The prophet reproves the community for its idols, iniquities, crimes, and abominations; and he warns against God's severe punishment of both the sinners among the people and prophets who succumb to the requests of the people.

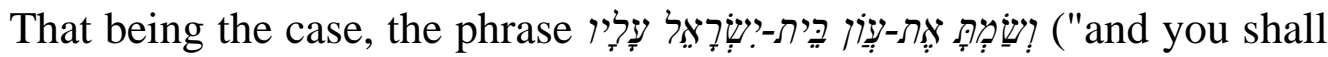
place the iniquity of the house of Israel on it"; Ezek 4:4) may be seen as a statement expressing the symbolism of Ezekiel's act in the section, in the same way that in 14:4, 7 the iniquities of the people are set before their faces (paralleling their setting up the idols in their hearts). Thus, in verse 4 this expression serves as a kind of headline to the entire section. Likewise, the

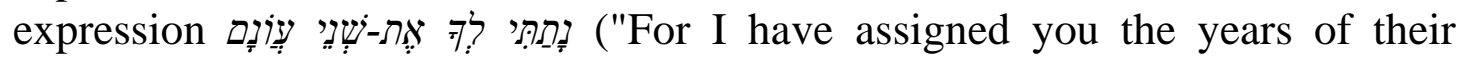
iniquity"; v. 5) and the end of verse 6 express the symbolism of Ezekiel's act of lying on the side, atoning the iniquity of the people (in light of the parallelism between עון + נתנ and Ezek 14:3-4, 7). In light of the context in Ezek 14:10, the phrase עון + עישו in verses 4-6 carries the meaning of bearing one's iniquity as a symbolic-declarative punishment. The symbolic suffering of the prophet entailed in the act of lying tied for an extended period of time atones for the sins of the people, each day symbolizing a year. It is noteworthy that the motif of a punishment lasting for forty years appears also in Ezek 29:11-12, in connection with the destruction of Egypt: "...it will not be inhabited for forty years. So I will make the land of Egypt a desolation in the midst of desolated lands. And her cities, in the midst of cities that are laid waste, will be desolate forty years..."). From here it can apparently be inferred that forty years is a classical typological period of punishment intended for an entire generation.

\section{DISCUSSION AND CONCLUSIONS}

As I mentioned in the introduction of this study, the Book of Ezekiel does not give information about the life of Judeans as exiles in Babylon. This information 
(though not in abundance) is available in epigraphic sources from Babylon, mainly the Murašû archive from Nippur. From the picture portrayed there, Judean exiles lived in the Nippur area during the Babylonian and early Persian periods. ${ }^{88}$ According to Abraham, the majority of them lived in small peripheral agricultural settlements, on lands given to them by the state, in return for tax paying and army service. ${ }^{89}$ Occasionally, Judean individuals from Âl-Yāhūdu ("The city of Judah") visited the capital Babylon for their businesses. Some of the Judeans held low-level administrative functions. ${ }^{90}$ It seems that as time passed, the Judean population in Babylon gradually integrated into Babylonian society (which itself was very ethnically diverse, especially in the Nippur area), though the ethnic-religious identity was preserved (according to the continuing giving of typical Judean names).

Although the figure of Ezekiel is physically placed in Babylon, his mind is obsessively occupied with Jerusalem and its destruction. Garber writes that reading the book of Ezekiel creates the impression that the speaker in the book has gone through a difficult trauma, has experienced loss and bereavement and witnessed atrocities. ${ }^{91}$ The harsh reality was conceived of as God's punishment of the sinning people. The terrible events are thus rationalized, the disaster becomes meaningful. Logic defeats the fortuitousness of historical reality. According to Poser, the notion of silence, which is expressed in the muteness scene, is the only appropriate reaction to the unbearably traumatic events. ${ }^{92}$ People suffering from PTSD often feel that speaking about their experience makes the horrific events banal. Indeed, sometimes silence says more than words. However, Ezekiel employs another strategy of responding to the trauma. He uses symbolization throughout the book, and in light of this context chapters 16, 23 and the peculiarities in Ezekiel's behaviour should be read.

Garber remarks that the trauma in the book of Ezekiel exists on two levels: the personal and the communal levels (and also on the theological level). ${ }^{93}$ Like a prophetic mission, the trauma takes control over all aspects of a person's life and disturbs his peace of mind. Garber views the "anomalies" and the eccentric symbo-

88 Laurie E. Pearce, "Identifying Judeans and Judean Identity in the Babylonian Evidence," in Exile and Return: The Babylonian Context (ed. Jonathan Stökl and Caroline Waerzeggers; BZAW 478; Boston: de Gruyter, 2015), 7-32.

89 Kathleen Abraham, "Negotiating Marriage in Multicultural Babylonia: An Example from the Judean Community in Āl-Yāhūdu," in Exile and Return: The Babylonian Context (ed. Jonathan Stökl and Caroline Waerzeggers; BZAW 478; Boston: de Gruyter 2015), 31-57.

90 Abraham, "Negotiating Marriage," p. 32.

91 David G. Garber, "I Went in Bitterness": Theological Implications of a Trauma Theory Reading of Ezekiel," Review and Expositor 111 (2014): 346-357.

92 Poser, "No Words," 38.

93 David G. Garber, "Traumatizing Ezekiel." 
lism in the book of Ezekiel as a literary attempt to illustrate to the reader or to the listener, the agitation of the prophet, as a voice coming from the exiled community.

Daschke, too, discusses the traumatic events related with the migration experience, and he, too, conjectures that the speaker in the book of Ezekiel suffers from post-traumatic symptoms. ${ }^{94}$ Not a mental disease in the full sense of the word is at play here, but a man suffering from melancholy, nostalgia, grief, and anger. Daschke, however, stresses that a process of recovery and reconciliation can be discerned throughout the book. For example, the descriptions of the future ideal temple in chapters 40-48 constitute a kind of therapy for the prophet's hurting soul. Moreover, the writing proses in itself is a way of coping with the trauma. Building the narrative is a major (first) step toward healing. ${ }^{95}$ Thoughts are thus made more ordered and rational. Art, as well as religious ritual, are prominent tools in the process of the narrative telling. It makes chaos "makes sense" and converts the healing process into a collective experience. ${ }^{96}$

According to the words of Herman cited in the first part of this study, the difficulty of finding an outlet for the extreme anger, the sense of frustration, and the helplessness following traumatic experiences often result in uncontrolled outbursts of rage. Sometimes the anger is directed towards the victim himself, due to the sense of guilt adhering to him. Chapters 16 and 23 in the book of Ezekiel express the fury of the author clearly and sharply through the use of blunt and violent sexual semantics. The voice of the speaker in the book of Ezekiel describes the sentiment of a certain school, or perhaps of an entire community, within the Babylonian exiles, who after having personally experienced the trauma of deportation and destruction now struggle to find a meaningful explanation for the disaster. Anger (or rage), being the prominent emotion embedded in chapters 16 and 23, can be seen as directed to the people of Judah and Jerusalem, Judah's leadership, near-eastern superpowers ravaging Jerusalem, and towards the exilic community which the prophet belongs to. Perhaps the exiles too, carry the responsibility for their harsh experience.

The literary post-traumatic "symptoms" in the sections discussed do not necessarily bear witness to clinical or behavioural symptoms among the authors of the book or the exiles in general, however their very appearance in the book of Ezekiel nevertheless testifies to the extreme difficulty of explaining the disaster and coping with it. The different diagnostic theories about the mental state of the speaker that have been suggested, and summarized in the present study (see Broome, Van Nuys, and Halperin), may stimulate our curiosity about the personal biography and the world of the author, however they have no true scientific basis, as already emphasized by Jobling, Garber, and Daschke. In

94 Daschke, "Desolate among them."

95 Frechette and Boase, "Defining Trauma," 6.

96 Frechette and Boase, "Defining Trauma," 7. 
contrast, the theories that focus on the literary symbolism of the book, such as the gender related theory set forth by Kamionkowski, teach us much about the conceptual world and socio-cultural norms of the author and his community. The authority, honour, and masculinity of the exiled males - heads of families and communities - suffered a devastating blow. They had suffered political, military, and social humiliation, and in some sense this may even have been perceived as a kind of sexual humiliation, in light of the dichotomy "strength = masculinity," "weakness = femininity." The speaker in the book of Ezekiel tries to cope with this situation and with these feelings in order to turn the table upside down. He, the victim, begins to identify with the perpetrator, the punishing God, and in this way the fury of the speaker "unites" with the fury of God towards sinful Jerusalem. At this stage, the masculinity and strength of the speaker in his role as the representative of his community and its leaders are reconfirmed, and he regains control. Chapters 16 and 23 illustrate the extent to which the pride of the exiles had been hurt, and how mentally unbearable the disaster had been. As Birnbaum notes, national traumas leave many individuals with personal traumas and post-traumatic symptoms in their wake. The "radical" deeds of Ezekiel lying on his side for an extended period of time, the pericope of the muteness, and the ecstasies of sexual abasement in chapters 16 and 23 - show the existence of "national-theological post-trauma," which made it necessary to explain and redefine the relations between the people and God. However, they also testify to the existence of a post-trauma on the personal and communal level, due to the subversion of the natural personal-psychological order that followed the national disaster.

\section{BIBLIOGRAPHY}

Abraham, Kathleen. "Negotiating Marriage in Multicultural Babylonia: An Example from the Judean Community in Āl-Yāhūdu." Pages 31-57 in Exile and Return: The Babylonian Context. Edited by Jonathan Stökl and Caroline Waerzeggers. BZAW 478. Boston: de Gruyter 2015.

American Psychiatric Association. Diagnostic and Statistical Manual of Mental Disorders. Fifth Edition; Washington DC: American Psychiatric Association, 2013. https://doi.org/10.1176/appi.books.9780890425596.

Amery, Jean. Beyond Guilt and Atonement (Hebrew). Tel Aviv: Am Oved, 2000.

Berger, Roni and Weiss, Tzipi. "Immigration and Posttraumatic Growth - A Missing Link." Journal of Immigrant and Refugee Studies 1 (2002): 21-39. https://doi.org /10.1300/J191v01n02_02.

Birnbaum, Aiton. "Collective Trauma and Post-Traumatic Symptoms in the Biblical Narrative of Ancient Israel." Mental Health, Religion and Culture 11 (2008): 533546. https://doi.org/10.1080/13674670701598565.

Block, Daniel I. The Book of Ezekiel: Chapters 1-24. NICOT. Grand Rapids: W. B. Eerdmans, 1998. 
Broome, Edwin C. "Ezekiel's Abnormal Personality." Journal of Biblical Literature 65 (1946): 277-292. https://doi.org/10.2307/3262666.

Carley, Keith W. Ezekiel among the Prophets. London: S.C.M. Press ,1975.

Cassuto, Moshe D. From Noah to Abraham (Hebrew). Jerusalem: Magnes, 1959.

Clines, David J.A. et al., "אחרית," Page 201 in vol. 1 of The Dictionary of Classical Hebrew. Edited by David J. A. Clines, Philip R. Davies and John W. Rogerson. 8 vols. Sheffield: Sheffield Academic Press, 1993.

Cooke, George A. A Critical and Exegetical Commentary on the Book of Ezekiel. ICC. Edinburgh: T \& T Clark, 1951.

Crager, Mia et al. "Forced Migration and Psychotic Symptoms: An Analysis of the National Latino and Asian American Study." Journal of Immigrant and Refugee Studies 11 (2013): 299-314. https://doi.org/10.1080/15562948.2013.801737.

Darr, Katheryn P. "Ezekiel's Justifications of God: Teaching Troubling Texts." Journal for the Study of the Old Testament 55 (1992): 97-117. https://doi.org/10.1177/ 030908929201705508.

Daschke, Dereck M. "Desolate among them: Loss, Fantasy and Recovery in the Book of Ezekiel." American Imago 56 (1999): 105-132. https://doi.org/10.1353 laim.1999.0005.

Davis, Ellen F. "Swallowing Hard: Reflections on Ezekiel's Dumbness." Pages 217-237 in Signs and Wonders: Biblical Texts in Literary Focus. Edited by J. Cheryl Exum, Atlanta: Scholars Press, 1989.

Day, Linda. "Rhetoric and Domestic Violence in Ezekiel 16." Biblical Interpretation 8 (2000): 205-230. https://doi.org/10.1163/156851500750096327.

Eichrodt, Walther. Ezekiel. OTL. London: SCM Press, 1970.

Eiorá Drasa, Francisco J., Brune, Michael, Huter, Katrin et al., "Belief Systems as Coping Factors in Traumatized Refugees: A Prospective Study." Traumatology 17 (2011): 1-7. https://doi.org/10.1177/1534765609358468.

Frechette, Christopher G. and Boase, Elizabeth. "Defining 'Trauma' as a Useful Lens for Biblical Interpretation." Pages 1-23 in Bible Through the Lens of Trauma (edited by Elizabeth Boase and Christopher G. Frechette, Atlanta: SBL Press, 2010. https://doi.org/10.2307/j.ctt1h1htfd.4.

Galambush, Julie. Jerusalem in the Book of Ezekiel: The City as Yahweh's Wife. Atlanta: Emory University, 1992.

Garber, David G. "'I Went in Bitterness': Theological Implications of a Trauma Theory Reading of Ezekiel." Review and Expositor 111 (2014): 346-357. https://doi.org/ 10.1177/0034637314557242.

Garber, David G. "Traumatizing Ezekiel, The Exilic Prophet." Pages 215-235 in vol. 2 of Psychology and the Bible: A New Way to Read the Scriptures. Edited by J. Harold Ellens and Wayne G. Rollins, Westport: Praeger, 2004.

Greenberg, Moshe. Ezekiel 1-20. AB. Garden City: Doubleday, 1983.

Greenberg, Moshe. "On Ezekiel's Dumbness." Journal of Biblical Literature 77 (1958): 101-105. https://doi.org/10.2307/3264590.

Gunkel, Hermann. "The Secret Experiences of the Prophets." Expositor 9, 1 (1924): 356-366, 427-433; Expositor 9, 2 (1924): 23-32.

Halperin, David J. Seeking Ezekiel: Text and Psychology. University Park: Pennsylvania State University Press, 1993.

Herman, Judith L. Trauma and Recovery. New York: Basic Books, 1992. 
58 Furman, “Trauma and Post-Trauma," OTE 33/1 (2020): 32-59

Jobling, David. "An Adequate Psychological Approach to the Book of Ezekiel." Pages 203-213 in vol. 2 of Psychology and the Bible: A New Way to Read the Scriptures. Edited by J. Harold Ellens and Wayne G. Rollins, Westport: Praeger, 2004.

Joyce, Paul M. "The Prophets and Psychological Interpretation." Pages 133-148 in Prophecy and the Prophets in Ancient Israel: Proceedings of the Oxford Old Testament Seminar. Edited by John Day, New York: T \& T Clark, 2010.

Kamionkowski, S. Tamar. Gender Reversal and Cosmic Chaos: A Study on the Book of Ezekiel. JSOT Supp. 368. London: Sheffield Academic Press, 2003.

Kasher, Rimon. Ezekiel. Miqrā' lěyiśrā'ēl. vol. 1. Tel Aviv: 'Am 'Oved, 2001.

Keil, Carl F. Biblical Commentary on the Prophecies of Ezekiel. Grand Rapids: W.B. Eerdmans, 1950.

Kivisto, Peter and La Vecchia-Mikkola, Venja. "Immigrant Ambivalence toward the Homeland: The Case of Iraqis in Helsinki and Rome." Journal of Immigrant and Refugee Studies 11 (2013): 198-216. https://doi.org/10.1080/15562948.2013 .759000 .

Klostermann, August. "Ezechiel: Ein Beitrag zu Besserer Würdigung seiner Person und seiner Schrift." Theologische Studien und Kritiken 50 (1877): 391-439.

Koehler, Ludwig and Baumgartner, Walter. "אחרית," The Hebrew and Aramaic Lexicon of the Old Testament on CD-ROM. Logos Library System. 1994-2000. Print ed.: Ludwig Koehler and Walter Baumgartner, eds. The Hebrew and Aramaic Lexicon of the Old Testament. 5 vols. Leiden: Brill, 1994.

Leys, Ruth. From Guilt to Shame: Auschwitz and After. Princeton: Princeton University Press, 2007.

Leys, Ruth. Trauma: A Genealogy. Chicago: University of Chicago Press, 2000. https:// doi.org/10.7208/chicago/9780226477541.001.0001.

Moughtin-Mumby, Sharon. Sexual and Marital Metaphors in Hosea, Jeremiah, Isaiah, and Ezekiel. Oxford: Oxford University Press, 2008. https://doi.org/10.1093/ acprof:oso/9780199239085.001.0001.

Pearce, Laurie E. "Identifying Judeans and Judean Identity in the Babylonian Evidence." Pages 7-32 in Exile and Return: The Babylonian Context. Edited by Jonathan Stökl and Caroline Waerzeggers. BZAW 478. Boston: de Gruyter, 2015.

Peña, Juan M et al. "Traumatic Events and Symptoms among Mexican Deportees in a Border Community." Journal of Immigrant and Refugee Studies 15 (2017): 3652. https://doi.org/10.1080/15562948.2016.1158341.

Pérez, Paule. "Exiles Masked, Masks of Exile." Diogenes 54 (2007): 73-80. https://doi.org/10.1177/0392192107086532.

Poser, Ruth. "No Words: The Book of Ezekiel as Trauma Literature and a Response to Exile." Pages 27-48 in Bible Through the Lens of Trauma edited by Elizabeth Boase and Christopher G. Frechette, Atlanta: SBL Press, 2010. https://doi.org /10.2307/j.ctt1h1htfd.5.

Rosen-Zvi, Ishay. The Mishnaic Sotah Ritual: Temple, Gender and Midrash (Hebrew version). Jerusalem: Magnes, 2008.

Schmitt, John J. "Psychoanalyzing Ezekiel." Pages 185-201 in vol. 2 of Psychology and the Bible: A New Way to Read the Scriptures. Edited by J. Harold Ellens and Wayne G. Rollins, Westport: Praeger, 2004.

Stiebert, Johanna. "Shame and Prophecy: Approaches Past and Present." Biblical Interpretation 8 (2000): 255-275. https://doi.org/10.1163/156851500750096345. 
Stulman, Louis. "Ezekiel as Disaster/Survival Literature: Speaking on Behalf of the Losers." Pages 133-146 in The Prophets Speak on Forced Migration. Edited by Mark J. Boda, et al., Atlanta: SBL Press, 2015. https://doi.org/10.2307/j.ctt1b7x $\underline{6 \mathrm{cn} .14}$.

Tedeschi, Richard, G. and Calhoun, Lawrence, G. Trauma and Transformation: Growing in the Aftermath of Suffering. Thousand Oaks: SAGE, 1995. https://doi.org/10.4135/9781483326931.

Torrey, Charles C. Pseudo-Ezekiel and the Original Prophecy. New Haven: Yale University Press.

van Nuys, Kelvin. "Evaluating the Pathological in Prophetic Experience (Particularly in Ezekiel)." Journal of Bible and Religion 21 (1953): 244-251. https://doi.org/ 10.1093/jaarel/XXI.4.244.

Wiesel, Elie. Night. New York: Hill \& Wang ,1960.

Wilson, Robert R. "An Interpretation of Ezekiel's Dumbness." Vetus Testamentum 22 (1972): 91-104. https://doi.org/10.1163/156853372X00505.

Zucker, David J. and Reiss, Moshe "Ezekiel as Misogynist." Biblical Theology Bulletin 46 (2016): 186-190. https://doi.org/10.1177/0146107916664053.

Refael Furman, Ben-Gurion University of the Negev, P.O. Box 653 Beer-Sheva, Israel 84105. E-mail: refaelf@ post.bgu.ac.il. ORCID: https://orcid.org/0000$\underline{0002-4305-1292 .}$. 